\title{
SHAKESPEARE'S OTHELLO BEYOND THE BOUNDARIES OF THE PAGE: AN ANALYSIS OF TWO FILMIC PRODUCTIONS
}

\author{
Camila Paula Camilotti \\ Universidade Federal de Santa Catarina
}

\begin{abstract}
This article aims at observing and analyzing two filmic productions ofWilliam Shakespeare's Othello. The first, entitled Othello, was directed, produced and starred by Orson Welles in 1952 andthe second, also entitled Othello, was directed by Oliver Parker in 1995. My main interest in studying these two filmic productions is to observe - based on the notions of theatrical adaptation by Jay Halio (2000), Patrice Pavis (1992), and Allan Dessen (2002) - how each director constructed the seduction moment that happens in Scene III, Act III of Shakespeare's playtext in their filmic productions. The analysis proves that two different conceptions, separated in time and space, are capable of making Shakespeare's timelessness transcend and make the modern spectators aware of the fact that the human artistic capacity is able to cross unimaginable limits of creativity and transform a great literary work of art in a great (filmic or theatrical) spectacle.
\end{abstract}

Keywords: Shakespeare's Othello. Welles' Othello. Parker's Othello. Conception.

I have't. It is engendered. Hell and night

Must bring this monstrous birth to the world's light. (II.I 403-404)

Whenever a text (in this case, a Shakespearian playtext) crosses the boundaries of the page to live in a theatrical or cinematic medium, with all its visual (and sonorous) elements, it has inevitably to go through several alterations in order to be seen and heard by an audience, in a certain time and space. Such alterations, which have to do with cuttings, verbal and visual interpolations, and scene alternations happen due to the fact that images and actions, in a theatrical or cinematic production, will replace many of the words written on the paper. The

Esta obra está licenciada sob uma Creative Commons - Atribuição 4.0

\footnotetext{
* Formou-se em Letras Português Inglês e suas Respectivas Literaturas pela Universidade Paranaense (2004), tem mestrado em Letras (inglês e Literatura correspondente) pela Universidade Federal de Santa Catarina (2010), com a dissertação: Political Shadows: Two Brazilian Adaptations of William Shakespeares Richard III e doutorado em Estudos da Tradução (PGET), pela Universidade Federal de Santa Catarina. Atua como professora de língua inglesa e suas respectivas literaturas na Universidade Estadual do Oeste do Paraná (UNIOESTE), no campus de Foz do Iguaçu. Tem experiência nas áreas de literatura inglesa, estudos da tradução (especificamente tradução intersemiótica) e ensino de línguas estrangeiras (especificamente inglês e italiano). Atuou como professora de língua italiana e língua inglesa nos cursos extra-curriculares da Universidade Federal de Santa Catarina. E-mail: camilapaulacamilotti@gmail.com.
}

Anu. Lit., Florianópolis, v. 20, n. 2, p. 11-24, 2015. ISSNe 2175-7917 
text (or the "language", as Jay Halio (2000, p. 4) defines it) will be only one element among others, such as, set design, characters, lighting, andmusic. Therefore, using the entire text in a theatrical or cinematic production is no longer necessary. Thus, the first step the director takes in the trip from page to stage (or to the big screens) isto "invade" the author's lines and work on them to transform words or passages written on the paper into image, action, and sounds.

It is not an easy process, though. As Patrice Pavis (1992, p. 24) puts it, "for a text to give birth to a performance is no easy matter."In this first phase of the creative process, thedirector has a turmoil of ideas and interpretations in his mind and has to make his decisions. Thus, as Alan Dessen (2002, p. 2) puts it, he has to deal with the "losses and gains" of his choices, which, sometimes represents a huge challenge. According to Dessen (2002, p. 2), "subsequent choices and adjustments then range from the tiny (a single word) to the massive (as when a two or three-part play is compressed into one)", not to mention those sublime (or complicated) moments of the text that demand an equally efficient visual interpretation.

Following this path, Dessen (2002, p. 3) defines two terms for the director's attitude of "invading" the playtext to take it to the stage or to the big screens: Rescripting and Rewrighting. The first, as Dessen puts it, "denotes the changes made by a director in the received text in response to a perceived problem or to achieve some agenda". That is, when the director "rescripts" the playtext, he makes some slight changes in its nature in order to put it in confrontation with the other elements of the performance in the mise-en-scène. Dessen reinforces his argument by listing some practices that involve "rescripting". According to the author (2002, p. 3), the director needs to "streamline the playscript and save running time by cutting speeches or entire scenes, eliminate obscurity, conserve telescoping together various lesser characters, sidestep stage practices appropriate to the Globe that might mystify today's playgoer or actor, and occasionally, cancel out a passage that might not fit comfortably with a particular agenda or "concept'".

In Welles' filmic production, for instance, a huge amount of lines and also entire scenes from Shakespeare's playtext were omitted, because the director - as he mentions in the interview with Peter Bogdanovich (1992, p. 286), published in the book This is Orson Welles - feared a long production and wanted his to be only 90 minutes long. By cutting a huge amount of lines from Shakespeare's text to save time, Welles omitted all Iago's soliloquies, which, I believe, seems to have put in disadvantage his characteristic as a villain and his complicity with the spectators.In Parker's Othello, the opposite happens. In this case, there is 
a filmic production of 2 hours in which Iago's soliloquies were not only kept, but reinforced. (The actor Kenneth Branagh speaks and looks at the camera, as if he were looking at the spectators - this technique was also used by Richard, in Richard III, directed by Ian McKellen, in 1995). Thus, the villainy of the character is enriched in this filmic version of Shakespeare's Othello. Only the essential lines were cut to "save running time", as Dessen puts it.

As regards the latter - Rewrighting - it characterizes, according to Dessen (2002, p. 3), "situations where a director or adaptor moves closer to the role of the playwright so as to fashion a script with substantial differences from the original." That happens when the director, wanting to raise a reflection on his audience about an aspect of the society (orabouta specific and recurrent political problem of the society) makes radical changes in the original playtext to adapt to his production.

After altering the text, or, as Dessen puts it, rescripting or/andrewrightingit, the director moves on to the construction of the other elements that surround the production, such as characters, set design, costume, and music. Halio (2000, p. 4), in Understanding Shakespeare's plays in performance, claims that, in the process of taking a playtext to performance, the director or the "script doctor", after altering the text, has to "find" the nonverbal elements in his production, according to his conception (or interpretation).

However, considering that the director does not have only one way of dealing with theseaudiovisual elements (since he does not have only one interpretation of the playtext), the term "find" used by the author could be replaced by "construct", since the director, when working on the elements of his production, construct them, according to his conception. What the audience sees in the mise-en-scène and what the spectator sees on the big screensis the result of a long (and hard) process of construction that started with that brief conception once asleep in the mind of the director and that, in the working process, through decision makings and choices, became real and concrete. As Dessen (2002, p. 4) puts it, "Any movement of a Shakespeare play [and any other play] from page to stage [or to the big screens] involves hundreds of interpretative decisions", and they are all connected to the director's perspective in relation to the original text.

Thus, I would say that the director's conception is the starting point for his production to exist. It is the fuel of inspiration that leads him in his choices and decisions. Therefore, taking all the aforementioned facts into account, I wonder what Orson Welles' and 
Oliver Parker's conceptions with Shakespeare's Othello are, especially as regardsthe seduction moment, which happens in Scene III, Act III of the Shakespearian playtext.

\section{Constructing Orson Welles' Othello}

Welles' Othello had a long and complicated trajectory before reaching the spectators. This filmic production was released in 1952, but it started to be produced and shoot in 1948 . Welles went bankrupt in the middle of the shots and had to interrupt the process for some time to save money to invest it in his own movie in order to continue the shootings. In the interview with Bogdanovich (1992, p. 283), Welles, who plays the title role,declares that, thanks to a person ${ }^{1}$, who borrowed him 7.000 dollars, the shootings could continue.But, when the actors were ready to start the shootings and the money was in "Welles' purse", the costumes were not ready yet. Then, curiously, not to waste time, Welles had the idea of shooting the scene of the Turkish bath, in which the only costumes the actors wear (and the only ones available at the moment) are towels.

But, despite all the hard time Welles and his cast had in shooting the film, Othello is a well-constructed production, composed, as Anthony Davies (1988, p. 100) puts it, with rather "refined techniques". According to the author, Welles' Othello, with all its filmic elements, is immersed in such a theatrical atmosphere that puts in evidence the Shakespearian poetry. In Davies words (1988, p. 100), "for the first time in the examination of specific Shakespearian films, we are faced with a film which aims at reconciling theatrical drama with the realism of non-theatrical spatial elements". This is possible, I believe, for Welles' Othello, except for the long shot of the seduction scene, in which Othello walks with Iago along the seashore, is composed by brief shots, like a "mosaic in time" (DAVIES, 1988, p. 101). And these rapid scene changes give the spectator the impression of watching a theatrical production, rather than a film. In addition, this theatrical atmosphere surrounds the beautiful scenario of Venice and Cyprus, constructed with the realism of the natural landscape where the film was shot ${ }^{2}$. As Davies (1988, p. 106) puts it, "the theatricality of constructed décor gives way to the realism of sea and sky, and to the architectural polarities of Venice and Mogador". All these visual elements provide Welles' Othello a singular beauty, which, I believe, is one of the reasons that led to its success at the time.

\footnotetext{
${ }^{1}$ In the interview, Welles does not reveal the name of this person and confesses that he gave him a role in the filmto thank him for the money.

${ }^{2}$ Interestingly, Welles tells in the interview with Bogdanovich (1992, p. 284) that his Othello was shot in four different cities in Morocco and in five different places in Italy.
} 
Besides the brief shots, the lights in Welles' Othello play an important role in highlighting the theatrical atmosphere of the movie. According to Davies (1988, p. 108), "with the progressive enclosure of the action, Welles deploys another source photographic and thematic articulation within the space of the frame: the dramatic opposition of light and darkness." Besides constructing a (beautiful) scenario of outdoor sunlight and indoor (artificial) lights, the shades of light, or, as Davies puts it, the chiaroscuro effect, seems to reveal important aspects of Othello's state of mind.

In scene IV, Act III, for instance, when Othello, after being "poisoned" by Iago, argues with Desdemona, the lighting effects show his face in the shadow, which seems to allude to the fact that Othello, in believing Iago's words, is going to the wrong direction or, walking in the shadows of the doubts. Another moment that the lighting effects play an important part is when Othello and Desdemona have their weeding night. Welles does not make it clear whether the lovers really consummate their marriage or not, for the only thing that we see are their shadowsreflected on the wall, in an image of Othello embracing Desdemona. By adding this effect, Welles seems to leave us with that doubt that exists in between the lines of the Shakespearian text: Was the lovers' marriage really consummated?

In Scene II, Act IV, when Othello murders Desdemona, the alternations of light and darkness are also relevant to the construction of this tragicand mournful moment. When Othello enters the room to kill his wife, the camera shows only his shadow on the wall. As he gets close to the bed, his shadow becomes darker and, with a monster-like voice in the darkness, he says, "It is the cause, it is the cause" (1994, line 1). The effect of his shadow, together with the tone of his voice in the delivering of these lines, seems to reinforce the terror and the tension of this moment.

In addition to these remarkable characteristics, Welles' Othello brings the spectators a surprise in its beginning: the film starts with a prologue in which the camera shows an image of Desdemona and Othello's funeral and Iago's imprisonment. That is, Welles starts his filmic production by telling the spectators the end of the story, just like he did with Citizen Kane, released in 1941. In the interview with Bogdanovich (1992, p. 288), Welles reveals that starting Othello by the end was a way he found to recall Shakespeare's strategy of telling the spectators the end of the story. In fact, I believe that this original and creative beginning seems to reinforce the tragic characteristic of this Shakespearean play.

As regards the seduction moment, Welles allows us to see a beautiful image of Othello and Iago walking along the seashore (it is, as aforementioned, the only long shot of 
the film) and, whereas they walk, Iago starts his "poisonous" discourse about Desdemona and Cassio. I would say thatin this very first moment of the seduction, as they walk, the villain, whose rendition is apathetic, does not seem to be involving Othello in the story. He does not even look at Othello and it seems that both walk along the seashore without any friendly involvement. I would say that this lack of ensemble acting ${ }^{3}$ between the actors in this particular production seems to put the intensity (and also the importance) of this temptation moment in disadvantage.

Then, the seduction passage continues as they enter the Othello's room. Iago continues with his poisonous discourse while he helps Othello with his clothes. Then, after saying "I am bound to thee forever" (1994, line 213), Othello walks towards the mirror, whereas Iago remains in front of the camera and Othello remainsin his back. At this moment, Iago says, "I see this hath a little dash'd your spirits" (1994, line 214). Then, Othello looks at his own image in the mirror again, as if he was starting to agree with Iago. Then, when the villain delivers the lines, "Ay, there's the point; as (to be bold with you) / Not to affect many proposed matches / Of her own clime, complexion, and degree" (1994, lines 228-231), Othello is still looking at himself in the mirror. This visual imagery seems to suggest that he is starting to feel suspicious about Desdemona and is starting to look at himself in another way. The confident man he was is being replaced by the suspicious man he is starting to be after hearing Iago's discourse.

When Iago continues his speech and delivers the line, "Foh, one may smell in such, will most rank, / Foul disproportions, thoughts unnatural" (1994, lines 232-233), Othello asks him to leave and rushes towards the wall, expressing discomfort. The image shown by the camera makes it clear that he feels unwell. Thus, he sits down on the floor and starts to reflect on Iago's words. At this moment, Desdemona enters the room, therefore, Othello's soliloquy, "Why did I marry? This honest creature, doubtless, / Sees and knows more, much more, than he unfolds" (1994, lines 242-243) was omitted and it was replaced by Desdemona's suddenly entrance, which, by the way, happens even before Iago's exit. When Desdemona gets close to Othello and touches his forehead with the napkin, since she sees that he feels unwell, he becomes aggressiveand by saying, "Let it alone" (1994, line 288), pushes her and drops the napkin on the floor and, as he leaves, he steps on it.

\footnotetext{
${ }^{3}$ Halio (2000, p. 73 ) defines ensemble acting as "one way to achieve coherence [in a performance]. When actors have been working together long and well, they pick up more than their cues from each other: they play off one another in stimulating and exciting ways."
} 
As Othello walks away from Desdemona, he stops in front of the mirror again, looks at his own image for some time and sees Desdemona's reflection on the mirror. Interestingly, her imageis reflected in a ratherdistorted way. I would argue that this visual imagery seems revealing, because it possibly alludes to the fact that Othello, after being poisoned by Iago, becomes "blind" and can only see through the villain's eyes, thus, he starts to see Desdemona in a rather misshapen way. This fact reminds me of Honningan's (1997) reflection on Othello's vision (is it impaired? Is he able to see with his own eyes or does he need Iago's eyes to see?). Moreover, the mirror seems to suggest that what Othello sees is only a (misshapen) reflection, that is, an abstract event that Iago tried to insert in his mind and infect him with bad and wrong thoughts about Desdemona and Cassio.

Then, after looking at Desdemona's image on the mirror for some seconds, Othello turns to her, walks towards her, looks at her, and touches her face. Then, the camera changes its focus to show a brief shot of Emilia collecting the napkin that is left onthe floor. After this brief shot, the camera returns to Othello and Desdemona. The couple is in silence. Othello looks at Desdemona for some seconds and, in silence, leaves her. Then, he walks towards their bedroomand look at their bed. Desdemona tries to follow him. Her expressions show clearly that she does not understand what is happening with Othello. The visual imagery of looking at the bed is also provoking. It seems to suggest that Othello is already poisoned and started to believe (and also see) Desdemona's treason.

As regards the text in Iago and Othello's dialogue, a huge amount of lines were cut by Welles, as aforementioned. The characters' conversation has a total of 214 lines in Shakespeare's text (it starts in line 92 and finishes with Othello's soliloquy in line 277). In this filmic production, the conversation between Iago and Othello, from the seashore to Othello's room, has about 99 lines. Welles cut about 115 lines out of 214. Othello's soliloquy, for instance, in which he reveals that Iago is honest and shows his doubt about Desdemona, was radically cut and it was replaced by Desdemona's sudden entrance in the room. Moreover, the end of the conversationwas slightly modified in Welles' production. In Shakespeare's text, Othello says "Farewell, Farewell! / If more thou dost perceive, let me know more;/ Set on thy wife to observe. Leave me, Iago" (1994, lines 238-240) and, as Iago leaves him, the Moor delivers his soliloquy, in which he reflects on marriage.

Then, Iago, who might have heard him, returns and says, "My lord, I would I might entreat your honor. / To scan this thing no farther; leave it to time" (1994, lines 244-245). In Welles' Othello, this line is said by Iago instead of Othello's soliloquy - "Why did I marry" - 
in which he reflects on marriage. Then, after hearing Iago's words, Othello says, "Farewell, farewell", however, the villain does not leave the scene, because when he is about to do it, Desdemona enters the room and he remains with the couple. The scene ends with an image of the three characters together in Othello's room.

I would say that the cuttings in Iago and Othello's conversation did not harm the scene as a whole. The seduction happens. Iago, despite his brief conversation with Othello, is capable of poisoning the Moor. So much so that from this scene on, Othello becomes rather aggressive and demonstrates, through his physical and facial expressions, his doubt and his discomfort. However, I believe that Iago's indifference with which he poisoned Othello does not seem convincing. The villainy of the character seems hidden in the actor Michaél MacLimmoir's apathetic performance.

As for the visual elements, I would say that the constant visual imagery of the mirror is rather revealing in this scene, for it seems to allude to Othello's doubt in relation to Desdemona and Cassio. In fact, the mirror, as I already mentioned, seems to suggest that what Othello sees after being poisoned by Iago is just a reflection. Since he does not have the "ocular proof" yet, he becomes influenced or rather infected by Iago's words.Personally, I would say that, despite MacLiammoir'sapathetic performanceas Iago, the seduction passage, constructed with all its visual imagery, is remarkably creative and leads us to a rich interpretation of this important (and indispensable) moment of the Shakespearian playtext.

Now, having discussed some important aspects of Welles' Othello, especially in what comes to the seduction moment, what is there to say about Oliver Parker's Othello?

\section{Constructing Oliver Parker's Othello}

Forty three years after Welles' inspired Othello, the homonym Shakespearian tragedy received another cinematic version. This time itwas produced and directed by Oliver Parker, in 1995. I would say that Parker's Othellois special for some visual imagery that seems to highlight, in a remarkably creative way, some important passages of the Shakespearian text.

Right in the beginning of the film, there is a beautiful (and also provoking) visual imagery of Othello and Desdemona in a Gondola, in Venice. Othello has a mask of the Greek tragedy, which seems a prediction of the tragedy that is going to happen in their lives. Then, after this image, the camera shows Parker's visual interpolation of their wedding, celebrated in a church (in the middle of the couple, there is a huge cross, which suggests that the wedding is Christian). Interestingly, the order of these visual imageries - firstly, Othello in a gondola with Desdemona, wearing a tragedy mask and, secondly, their wedding - seems to

Anu. Lit., Florianópolis, v. 20, n. 2, p. 11-24, 2015. ISSNe 2175-7917 
suggest that their marriage will end up in tragedy. Whereas Welles' Othello starts with the couple's funeral, Parker' Othello starts with a slight indication of this tragedy that is going to happen in the end.

Another visual imagery that is rather revealing in Parker's Othello is in the end of Scene III, Act I, when Iago, the night before the arrival in Cyprus, delivers his soliloquy in which he reveals his strategy to harm Othello and take Cassio's place. When he delivers the following line, "To get his place and to plume up my will / In double knavery - How? How? - Let's see" (1994, lines 393-394) he puts, respectively, the chess pieces - the black King, the knight, and the white queen - on the game board. Then, he observes his "strategy" for a while and, looking at the position of the pieces, delivers, "I have't. It is engend'red. Hell and night/ Must bring this monstrous birth to the world's light" (1994, lines 403-404), Then, he takes the pieces out of the board and the scene ends with the noise of thunder and with a lighting that seems to announce the storm. (It could also be considered the prediction of the "storm" that Iago, with his bloody strategies, will provoke in Othello's life). Interestingly, the position of the pieces on the chess board predicts a checkmate.

The visual imagery of the chess returns in the end of Scene I, Act V, before Desdemona's murder. As Iago delivers his soliloquy, "This is the night / That either makes me, or foredoes me quite" (1994, lines 128-129), he puts the chess pieces - the black King and the white Queen - on the edge of a sink and, in the end of his soliloquy, he throws them in the water. The image of the pieces falling into the water is the same image that is shownin the end of the film, when the bodies of Desdemona and Othello are thrown into the sea. That is, once more, this visual imagery predicts the tragedy that is about to happen in the couple's life.

Another interesting (and also rather revealing) visual imagery happens in Scene I, Act II, at the arrival at Cyprus. When Desdemona arrives with Emilia and the gentlemen, Cassio has a brief conversation with Desdemona about Othello's arrival. At this moment, Iago, who is standing some steps ahead of them, peels a fruit with a knife. Then, while he delivers his soliloquy, "He takes her by the palm; ay, well, said, whisper. / With as little a weh as this will I ensnare a great a fly as Cassio" (1994, lines 167-169), he sees their reflection on the knife. This provoking visual imagery seems to predict, like the pieces inthe chess board, the tragedy that is about to happen in Desdemona and Othello's lives, because of Iago's evil plans. The knife, in this particular moment, is a visual element that seems to suggest death, crime, and blood. 
In addition to these meaningful and rich images, there is another visual surprise in Parker's filmic production, in the end of Scene III, Act III, when Iago and Othello establish a complicity pact. In the Shakespearian text, the stage directions suggest that the characters kneel before "exchanging their vows". In Parker's Othello, the characters not only kneel, but establish a blood pact, which, I believe, is are markably strong visual imagery. Othello is not only giving his word to Iago, but an essential part of his own self: his blood. When Othello says, "Now by yond marble heaven, / In the due reverence of a sacred vow / I here engage my words" (1994, lines 460-462), he gets close to Iago, cuts his hand with his sword, shedding his blood. Then, Iago does the same and, when Othello says, "I greet thy love" (1994, line 470), they touch hands, establishing their blood pact. I would say that the ties they establish at this moment are even stronger than Othello and Desdemona's marriage. Moreover, the blood pact of the characters fit perfectly to Iago's last lines, "I am your own for ever." (1994, line 480)

These strong visual imageries added by Parker are also remarkably present in the seduction moment, which, as aforementioned, happens in Scene III, Act III of the Shakespearian text. Here, in this scene, Parker allows the spectators see clearly the moment Iago's poison enters Othello's mind and transforms him in a mistrustful man. The seduction moment happens in three different places: it starts in the yard of the castle, then, it moves on to the weapons room, and finishes in Othello's room.

Iago starts to sow the seed of mistrust and doubt in Othello's mind in their staff fighting in the yard of the castle. Desdemona and Emilia watch their "fighting game" from the balcony and, when they end their game, Othello looks at Desdemona and says out loud that he loves her: "Perdition catch my soul / But I do love thee!" (1994, lines 90-91). Atthis moment, Iago takes advantage of this love declaration and starts to poison the Moor by asking him about Desdemona's friendship with Cassio. Then, their conversation continues in the weapons room and, as Othello washes up, he asks Iago the reason of his question. Then, when Iago answers, "but for a satisfaction of my thought, / No further harm" (1994, line 97), he is "innocently" taking notes in a notebook.

Then, their conversation continues normally and, whereas Iago delivers his lines questioning Cassio's honesty, Othello manages a weapon and delivers, "I prithee speak to me as to thy thinkings, / As thou dost ruminate, and give thy worst of thoughts / The worst of words" (1994, lines 131-132). Iago, whoobserves Othello from a seat, continues on his reflection about Cassio's honesty and tries to convince the Moor that his lieutenant is not 
loyal. Then, whereas Iago delivers the line, "Good name in man and woman, dear my lord, / Is the immediate jewel of their souls" (1994, lines 155-156), Othello puts his (loaded) weapon upon his shoulder and, with a rather serious expression, gets close to the villain. Then, he looks at Iago and, pointing his weapon to him, says, "I'll know thy thoughts" (1994, line 162), and Iago, in a remarkably expressive and convincing way, looking into Othello's eyes, delivers the following lines: "O, beware, my lord, of jealousy! / It is the green-ey'd monster which doth mock / The meat it feeds on. That cuckold lives in bliss who, certain of his fate, loves not his wronger; / But O, what damned minutes tells he o'er / Who dotes, yet doubts, suspects, yet [strongly] loves!" (1994, lines 165-170). However, Othello, for what it seems, still feels confident about Desdemona's loyalty.

He starts to reflect seriously upon Iago's words onlywhen the villain delivers his famous line: "Look to your wife, observe her well with Cassio" (1994, line 197). After hearing these words, Othello does not say a word. Remains in silence and looks at the floor, as if he were "digesting" Iago's words. Then, the villain, observing his silence, delivers, "I see this hath little dash'd your spirits" (1994, line 214). Othello tries to disguise his discomfort, but he cannot. His face shows a rather serious and worried expression. It is clear that he started to feel emotionally touched by Iago's poisonous discourse.

However, the moment Iago's poison really enters Othello's mind (and Parker shows it clearly through the visual imagery he adds at this moment) is when Iago delivers the following words: "Ay, there's the point; as (to be bold with you) / Not to affect many proposed matches / Of her own clime, complexion, and degree, / Whereto we see in all things nature tends - /Foh, one may smell in such, a will most rank, Foul disproportions, thoughts unnatural" (1994, lines 228-233). At this moment, the camera shows, in a panoramic shot, Iago's mouth near Othello's ear. Whereas Iago delivers these lines, Othello starts to imagine Desdemona with Cassio. Then, the camera shows an image of them together, dancing, and kissing. By seeing this image, we are able of entering Othello's mind and "see" Desdemona's treason the way that Othello starts to "see" it.

Thus, whereas Othello imagines Desdemona with Cassio, Iago's words turn to a whispering. Then, after this brief image of the couple, the camera shows Othello's face again and Iago delivers the last line of his speech, "But (pardon me) I do not in position / Distinctly speak of her, though I may fear / Her will, recoiling to her better judgment, / May fall to match you with her country forms, and happily repent" (1994, lines 234-237). When Iago finishes his speech, the camera shows him in Othello's room helping the Moor with his 
clothes. Othello's expression at this moment is completely changed. He is serious and rather reflexive. It is clear thatlago has finally achieved his goal of "infecting" Othello with his poison.

Then, after asking Iago to leave by saying, "Farewell, farewell" (1994, line 238), Othello delivers his soliloquy "Why did I marry?" (1994, line 242) Iago, at the door, hears him and answers: "My lord, I would I might entreat your honor / To scan this thing no farther; leave it to time" (1994, lines 244-245) and leaves. At this moment, Othello, alone in the room, sits on his bed and, feeling unwell, delivers only this first line of his soliloquy: "That we can call these delicate creatures ours, and not their appetites!” (1994, lines 269-270). After saying these words, the Moor, once more, imagines Desdemona with Cassio. He sweats and seems to feel physically sick. The image shown by the camera of Desdemona and Cassio, as a reflection of Othello's imagination, is interrupted by Desdemona's entrance in the room. She realizes Othello's physical discomfort and touches his forehead with the napkin. The Moor does not react aggressively as Welles' Othello does, and, feeling suspicious, leaves the room with Desdemona. As they leave, she forgets the napkin on the bed and Emilia takes it.

In what concerns the text, I would say that, in comparison to Welles' scene, there is less cuts in the conversation between Othello and Iago. Specifically, Parker cut only 72 lines out of 214. The seduction moment is longer and, I would say, more thrilling in this filmic production than in Welles'. It seems that, by leaving some more lines and, consequently, making the seduction scene longer, Parker seems to have given more space and time for the seduction to happen. Iago, in this Othello, could take his time to sow the seeds of doubt in Othello's mind.

Besides, the seduction moment is closer to the Shakespearian text in Parker's Othello than in Welles'. For instance, Parker did not change the end of the scene. He follows exactly the same order of the conversation between the characters, that is, he does not make any alternation in the lines as Welles did. In the end of the scene, the stage directions in the text suggest that Iago leaves Othello and returns after the brief soliloquy delivered by the Moor, in which he reflects on his marriage. In Parker's filmic production, the same happens. Iago leaves and returns. When Desdemona enters the room with Emilia, Iago has already left.

Overall speaking, I believe that the temptation moment in this Othello is remarkably well constructed for two main reasons. The first has to do with the powerful and meaningful visual imagery added by Parker, before, during, and after Iago's poisoning. The second reason has to do with the good involvement the actors Lawrence Fisher, as Othello and Kenneth 
Branagh, as Iago demonstrated in the rendition of their characters, especially in this moment of the scene. The ensemble acting between them is clear and it happens, I believe, due to the expressive way with which they performed their roles.

\section{Final remarks}

I may conclude this paper saying that both directors were remarkably creative in the difficult process of taking Shakespeare's text to performance. Welles, despite all his difficulties in shooting the film, was able to produce a film immersed in a theatrical environment andin a beautiful scenario, which highlights, with a remarkable originality, the Shakespearian poetry. Besides, the lighting effects were efficiently used in this filmic production, both to construct the scenario and to highlight Othello's states of mind, especially after being poisoned by Iago. However, I would say that the actor Michaél Mac Liammóir's performance as Iago was not efficient enough to convince the spectators he was a villain. The apathetic way with which he expressed himself and delivered his lines seems to have put in disadvantage Iago's double-faced personality and his ensemble acting with the other characters, especially with Othello.

As regards Parker's Othello, I would say that it is also a remarkably creative filmic production, especially in what comes toits visual imagery. Moreover, Iago's soliloquies in this Othello are reinforced and, together with the remarkably expressive way with which Kenneth Branagh delivered his lines and performed his role, put in evidence, in a rather efficient way, the character's evil personality. Here, Iago is able to manipulate the characters as if they were really chess pieces in his strategic "chess board" and could successfully lead them to the tragic "checkmate" in the end.I dare say that Branagh's rendition as Iago in Parker's Othello is one of the facts that contributed to the success of this filmic production.

As last words, I would say that these two filmic versions of Shakespeare's Othello, separated in time and space, with all their visual and verbal elements, were capable of bringing Shakespeare and his poetry to our contemporaneity and prove that the bard's timelessness is due to the fact that his plays can be continually "rescripted" and "rewrighted"according to different conceptions and different interpretations.

\section{References}

BOGDANOVICH, Peter. Holywood. Este é Orson Welles. Trad. Beth Vieira. São Paulo: Editora Globo, 1992, p. 260-302. 
DAVIES, Anthony. Orson Welles's Othello. In: . Filming Shakespeare's plays: The Adaptations of Laurence Olivier, Orson Welles, Peter Brook, Akira Kurosawa. Great Britain: Cambridge University Press, 1988, p. 101-118.

DESSEN, Alan. Rescripting Shakespeare: The Text, the Director, and Modern Productions. Cambridge: Cambridge University Press, 2002.

HALIO, Jay Halio. Understanding Shakespeare's Plays in Performance. Houston: Srivenery Press, 2000.

HONNINGAN, E.A.J. Introduction. In: . Othello. Arden Third Series. Walton-onThames: Thomas Nelson, 1997, p. 1-111.

OTHELLO. Produção de Oliver Parker. Estados Unidos: Warner Bross Pictures, 1995. 1 CDRom.

PAVIS, Patrice. From page to Stage: A Difficult Birth. In: . Theatre at the Crossroads of Culture. London and New York: Routledge, 1992, p. 24-47.

SHAKESPEARE, William. The Riverside Shakespeare. USA: Haughton Mifflin, 1994.

OTHELLO. Produção de Orson Welles. Estados Unidos: Mercury Production, 1952. 1 CDRom.

[Recebido em maio de 2015 e aceito para publicação em junho de 2015]

\section{Otelo de Shakespeare além das fronteiras da página: uma análise de duas produções fílmicas}

Resumo: O objetivo deste artigo é observar e analisar duas produções fílmicas da obra Otelo, de William Shakespeare. A primeira, intitulada Othello, foi dirigida, produzida e estrelada por Orson Welles em 1952, e a segunda, também intitulada Othello, foi dirigida por Oliver Parker, em 1995. O interesse principal do estudo dessas produções é observar - à luz dos princípios de adaptação teatral de Jay Halio (2000), Patrice Pavis (1992), e Allan Dessen (2002) - como cada diretor construiu em suas produções fílmicas o momento da sedução que acontece na Cena III, Ato III, do texto shakespeariano. A análise aponta que duas concepções diferentes, separadas no tempo e no espaço, são capazes de fazer com que a atemporalidade de Shakespeare transcenda e mostra aos espectadores modernos que a capacidade artística humana é capaz de atravessar fronteiras inimagináveis de criatividade e transformar uma grande obra literária em um exímio espetáculo (fílmico ou teatral).

Palavras-chave: Otelo, de Shakespeare. Othello, de Welles. Othello, de Parker. Concepção.

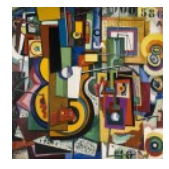

